\title{
Marketing the Library in an On-line University to Help Achieve Information Literacy
}

\author{
By Jennifer Murphy
}

\begin{abstract}
An entrepreneurial librarian takes the embedded librarian concept one step further at a completely on-line university and markets the virtual library to students, faculty and administration rather than wait for customers to come to the library. York and Vance (2009) make the observation that "one obstacle to marketing an embedded librarian service is that there is no consensus on what to call this practice" (p. 206). This librarian agreed and as her goal was to "win favor and confidence by imperceptible degrees" (Merriam-Webster, 2013) she chose to call it insinuation of the library.
\end{abstract}

\section{Introduction}

An on-line library has no point of purchase, a counter where the customer buys the product, to entice the buyer. Unlike a brick and mortar school, where the reference counter serves as the point of purchase and is "intended to make approaching the desk for help less intimidating", an online library needs to find a comparable point of purchase to encourage its customers to approach the imaginary desk (Duke, MacDonald and Trimble, 2009, p. 111). As stated by Gandhi (2002), when speaking of marketing to distance students, "academic librarians have to proactively promote their services to distance learners" as well as, to faculty and administrators (p. 151). Marketing is defined as "the activities that are involved in making people aware of a company's products, making sure that the products are available to be bought, etc." (Merriam-Webster, 2013) and is a universal term whether your product is a car or an online library.

The University set a lofty goal of increasing retention of its students by ten percent in a year and the librarian was convinced that increasing information literacy by insinuating the library and its services into the classroom would contribute to the achievement of this goal. However, when she attempted to find the university's information literacy standards she found that, although the student handbook's "Learning outcomes" referenced life-long learning skills, leveraging information and technology to achieve goals, and the ability to solve real world problems, there was no formal policy. The Standards for distance learning library services adamantly stress that students are entitled to become information literate by the time they graduate, and that it is the library's mandate to ensure this happens (ACRL, 2008, p. 565). Being an on-line student should not be a detriment as emphasized by the ACRL standards "principle of access entitlement" which states every distance learner has the right to access the same information and learn the same information literacy skills that a student in a brick and mortar college would learn (ACRL, 2008, p. 558). It was clear to the librarian that in order to achieve an increase in library sales, so to speak, she must first convince the administration that [the University] needed to embrace the importance of information literacy by developing written standards. The bones of information literacy were there, but needed some flesh on the skeleton. It was not sufficient to simply increase the number of library customers by increasing database usage, it was necessary to increase information literacy in general.

\section{Background}

"In 1999 [the University] became the first accredited private virtual university without a physical campus" (Gandhi, 2003, p. 139). Founder, Glenn Jones, believed passionately that education should be available to everyone, everywhere; a belief echoed by the American Library Association as stated by Saunders (2008) "the free flow of information, and the knowledge to access and interpret that information, is essential to American society (p. 305). However, in June 2011 [the University] was placed on notice by its accrediting agency, the Higher Learning Commission (HLC). One of the concerns cited was improvement of retention rates in all programs, but especially the undergraduate. [The University] made incredible strides in complying with concerns of the HLC and were taken off notice in July 2013. However, retention remained a high priority for 
[the University] and the librarian felt the library could implement effective and measurable programs to assist in this goal. The HLC does not stress information literacy as heavily as other accreditation commissions, such as the Middle States Commission on Higher Education which states information literacy is a "necessary requirement of undergraduate education", and information literacy was not cited as a concern in the HLC report to [the University] ("Standards for Accreditation and Requirements of Affiliation," 2006, p. 56). However, it is inferred in the HLC Criteria for Accreditation (2012) "The organization demonstrates that acquisition of a breadth of knowledge and skills and the exercise of intellectual inquiry are integral to its educational programs." And, promoting and enabling life-long learning, particularly in the undergraduate program, is emphasized in their criteria (Criterion Four: Acquisition, Discovery, and Application of Knowledge). The librarian, having managed a business for fifteen years before making a gratifying change in careers, decided to approach the problem as she would have in marketing her business. Unfortunately, "The traditional viewpoint of marketing can be problematic to LIS because it invokes images of advertising, or maximizing sales, tasks more generally associated with business perspectives" (Brown and Albright, 2013, pp. 22-23). Alternatively, the librarian's marketing objective was to embed the library and in turn significantly affect student's information literacy skills. According to West-Pawl (2012) "It is imperative that librarians are embedded into the courses not only to teach students how to search library databases, but also to teach information literacy" (The Embedded Librarian).

\section{Developing a Marketing Plan}

A study, conducted by Connaway, L. S., \& Dickey, T. J. (2010) discovered the need for libraries to advertise. A briefing on the study concludes "The library must advertise its brand and its resources better to academics, researchers and students, demonstrating its value clearly and unambiguously" (Researchers and Discovery Services, para. 1). Combining marketing and libraries is not a completely novel concept. Duke, MacDonald and Trimble (2009) discuss the collaboration between a marketing class and the library at Illinois Wesleyan University in which the marketing class was given the assignment of producing promotional campaigns for the library (p. 112). A survey conducted by the spring marketing class produced the rather disturbing conclusion that "no participants reported that they would begin a research project by consulting a librarian" (Duke, MacDonald and Trimble, 2009, p. 114). The fall marketing class, then assigned the task of developing a promotional campaign, decided students were not aware of the reference services that were available to them, but of more concern was the "students' reluctance to ask for assistance" (Duke, MacDonald and Trimble, 2009). This is prevalent in brick and mortar libraries, but the same hurdle exists for on-line libraries.

Although, it is easier for many to communicate impersonally through email rather than approach a librarian in person, there is still reluctance to ask for help. According to West-Pawl (2012), students who have received assistance from a librarian embedded in a class will develop a relationship and be more likely to ask for help from the library in the future (The Embedded Librarian). When the librarian becomes a fixture in the virtual classroom, students feel comfortable asking questions they might not normally seek out the librarian to ask. Unlike Illinois Wesleyan University, [the University] was under both budget and human resource constraints, so theirs was destined to be a one-librarian campaign. A course of action was beginning to surface and two components were targeted for the marketing plan: developing an information literacy policy and embedding the library in a course with the goal being increased information literacy skills and with a residual outcome being increased retention.

\section{Developing an Information Literacy Policy}

Clarifying and defining information literacy was the initial obstacle to developing a product to sell. While many articles defined information literacy in unique ways, there were common threads amongst them all and it was these that solidified [the University's] definition:

The ability to:

- Recognize when information is needed 
- Define the problem

- Evaluate and select appropriate resources

- Access and acquire information

- Understand how to adapt and/or apply that knowledge

- Understand the legal and ethical obligations related to the access and use of information, including avoiding plagiarism and using correct citation.

Although, the two components of embedding the library and developing an IL policy were worked on congruently, for clarity the two processes will be addressed separately. The first step in any marketing plan is to define the customer; that is, to whom did the librarian need to "sell" the product, in this case, the information literacy policy. Although, the student is the eventual benefactor it was determined that the customers were actually administrators, course experts and faculty, in that order. If these three groups did not embrace the policy it would never reach the light of day. As stated by Forbes (2007), "the university as a whole should accept responsibility for preparing and educating information literate citizens" (p. 237). Concurring with Owusu-Ansah that "Nothing thrives in academe without the blessing and encouragement of the administration" they were first targeted as a customer $(2004$, p. 6$)$. The librarian knew she could sell the product to administration by tying in HLC requirements which include, "life of learning" and "continued learning." Placing these at the forefront of [the University's] IL policy was the key to buy-in from administration. Another key to obtaining support was to make the connection between Information Literacy and increased retention. The librarian determined the first customers to set eyes on the policy should be the Academic Leadership Team which consisted of the Chief Academic Officer (CAO), Dean of Academic Administration (DAA) and faculty. The librarian was fortunate to have the support of the DAA, who is her immediate supervisor during the presentation and, after the presentation, the buy-in of the CAO, who sent out a campuswide letter stating "We're going to take [the librarian's] work, and... line up end of course objectives and end of program objectives to the goal of informational literacy" one of those objectives being retention. The product may have been sold, but it was still to be determined how to implement it so that the students would benefit. As stated by Owusu-Ansah (2004), although everyone in the organization believes in the principles behind information literacy, "concurrence on concrete steps to achieve it are often distant, at best" (p.3). After receiving this vote of confidence from administration, the librarian felt in order to make it more concrete, the next step was to get the Information Literacy Standards in print, so to speak. The librarian, therefore, attained permission from the Academic Council to have it published in both the on-line Faculty and Student Handbooks under "Learning Outcomes" (Appendix A).

\section{Insinuating the Library}

The real turning point came when the librarian was approached by a course expert who was redesigning English 101 and had heard from an administrator that the librarian was attempting to embed herself in a course. The course expert asked the librarian to help model a research question that would encourage students to consider how their degree would help them achieve their career goals and eventually developed the framing question "What qualifications will I need to acquire through my degree to succeed in my chosen career?" The librarian agreed with Matthew and Schroeder (2006) that "When a librarian is embedded in a course that lacks an explicit research component, the librarian's services go untapped" therefore, embedding information literacy and insinuating herself in a research course would be the most effective approach (p. 63). A study by Bowler and Street (2008) showed "significant improvement in students' scores when a librarian was conspicuously and obviously embedded" and when "IL was identified as specialized knowledge" (p. 438). Conversely, there was little improvement when an attempt was made to embed information literacy without expressly defining IL and the role of the librarian. The framing question was woven throughout the course and, not only was the librarian embedded in the course forum, but the library was embedded in a specific research assignment (Appendix B). According to Fister and Eland (2008), "students are more likely to be motivated to learn 
material if it has the immediate and obvious benefit of helping them complete a particular assignment successfully" (p.95). A belief reinforced by Riedel (2002) who believes "library assignments for an individual course should contribute to the students' information literacy (p. 483).

Tumbleson and Burke (2010) describe how the librarians at Gardner-Harvey Library, a regional campus of Miami University Middletown, decided to market their embedded librarian program when "Embedded librarians realized that research action no longer swirls around the reference desk nor the library Web site, but in students' online learning space otherwise known as course management systems"(p. 974). With this in mind, the librarian was introduced to the class via JESS, [the University's] online course management platform, in the beginning of the course. She became actively involved in the forum discussions, not only answering specific questions, but monitoring students' discussions and interjecting advice when it seemed appropriate. Gandhi (2003) observes "Academic librarians need to be more proactive in creating a more "visible" and sustained presence in distance education courses by actively participating in bulletin board and e-mail discussions" (p. 143). For example, in response to postings by many students with the same theme of paraphrasing and citation, the librarian posted "I thought I'd jump in here because a lot of people don't realize if you "paraphrase" someone's work you need to cite it. It's OK to change the wording, but if the idea is the same you should cite the author(s) and page number where the information was found..." Like Markgraf (2004), the librarian posted tips in the forum related to the assignments and discussions occurring that week "to ensure that they were what the students needed, precisely when they needed it" (p. 10).

In full agreement with Lih-Juan \& Chwen-Chwen Chang (2003) when they stated, "Policy support and cooperation from school faculty members are essential for successful implementation", the course instructors were the next market to be targeted and, rather than waiting to be invited into the faculty inner-circle, the [University] librarian essentially insinuated herself into the academia club. As Owusu-Ansah (2004) so eloquently stated "The academic library has the historical, intellectual, and institutional wherewithal to enrich the teaching-learning experience" (p.5). With that said, many librarians face the difficulty of feeling they are not on par with the faculty when it comes to teaching information literacy which is complicated by the fact that some faculty actually believe this to be true. A study by Scheuermann demonstrates that "if the professor doesn't encourage and foster engagement between the student and librarian, it may not happen" ("InstructorLibrarian", 2005). While some instructors embraced this belief and were overwhelmingly supportive of the librarian's embedment, others still had the age-old superiority over librarians complex, or at least a large amount of territorialism, as demonstrated by the responses of two instructors to a posting made by the librarian:

Instructor \#1 to her students: "I also see a very useful post by librarian... feel free to respond to any of the librarian's posts in the forum space with your input and feedback. You're very fortunate to have such a presence from the librarian in the forum space and make the best use of it."

Instructor \#2 to the librarian: "It would help very much if you would send me a list of the posts you intend to make. If I am unaware of the research focus you will bring, there is the potential for conflicting messages. "

Rather than become defensive, as instinct dictated, the librarian decided upon reflection that here was an opportunity to establish "a relationship of mutual trust in which the faculty member feels comfortable sharing editorial control of the courseware content" (Shank \& Dewald, 2003, p. 42). By following this advice to "work with diplomacy and aplomb" the librarian soon had a mutually respectful, if not friendly, relationship with the instructor who was initially not so welcoming" (Shank \& Dewald, 2003, p. 42). Bennett and Simning (2010) believe "when an instructor emphasizes the importance of the librarian as a resource for students, more weight and value are added... and students are much more likely to reach out to the embedded librarian for assistance" and this was indeed the librarian's experience (p. 454). 


\section{Results}

The librarian strongly agrees with Tyler and Hastings (2011) that digital information literacy should not be assumed because a generation has grown up using the Internet and other technology (p. 21). Comments from students, made either directly or indirectly to the librarian, corroborate this opinion and made it abundantly clear that most of these undergraduate students needed to be taught information literacy. There were a total of 74 students in the English 101 course in which the [University] librarian was embedded and out of those, she received requests for 6 research instructions and multiple questions through the forum. One of the assignments expressly asked students to describe the experiences they had in locating resources in the [University] Library and if a librarian was contacted, to describe that experience. There was a wide range of responses including:

"Using the [University] Library was not exactly all that helpful as I was hoping, or better yet, expecting... To be quite honest, I would rather stick with Google."

"Even though it was a challenge I am very glad we were urged to use the library. I will now know another place to find information for this and other classes to come later in my program. I will definitely use this feature again in the future."

"Yes, the [University] Library is a hard nut to crack, but I think the more you can use it the better you will become at searching terms."

"Yes, asking the librarian for help was pivotal for me..., the librarian also caused me to feel excited about the research."

"I found it hard to navigate through the library and find information. I had more success searching through the internet and finding all the answers to my questions through Bing and Google." "My experience researching in the [University] Library improved as a result of an on-line chat with a librarian."

A common thread throughout the forum was that students were initially frustrated by not knowing how to begin their search in the library. Some students were able to overcome this and others were not, but if the librarian had not only been available to answer questions, but had proactively taught the students research skills, they would have been more successful. The librarian did not want to overstep her bounds and infringe on the instructor's territory, which may have contributed to her reticence, but she strongly agreed with Bowler and Street's (2008) conclusion that "when information literacy is embedded consciously and conspicuously" in courses there is a calculable improvement (p. 439). Therefore, stepping on toes or not, the librarian must be more present in future courses and her reason for being there made more explicit. It was clear that just embedding information literacy in a course, without the very active participation of the librarian, was very frustrating for the students.

\section{Conclusion}

The librarian's business plan was to market her product to customers thereby increasing sales and realizing a profit. For an on-line library this translated to embedding the library in the forum thereby promoting usage and realizing an increase in information literacy. Students were asked at the end of the course to answer the question "Have there been any surprises along the way as you have engaged in writing a research-based essay?" Thirty-five students supplied feedback directly related to the library which was collated and broken down as follows:

Did use the librarian- 9

Did not, but will use the librarian in the future- 3

Found the library hard to navigate initially, but it got easier/was worth the effort-8 
Specifically stated will use library in the future- 5

Specifically stated will not use the library in the future-10

The librarian overall was happy with the results of her first foray into English 101, but felt ten students claiming they would not use the library in the future was unacceptable. English 101 was the appropriate class in which to be embedded because of its research component, as well as, the requirement that students use the University library to complete an assignment. However, in future, she will be even more proactive in reaching out to students and posting research advice before their assignments. She believes insinuating herself and the library is a strong step toward information literacy. True success came from embedding the library and information literacy in the class, but comments from students prove the librarian needs to be involved and embedded, as well.

\section{References}

Bennett, E., \& Simning, J. (2010). Embedded librarians and reference traffic: An analysis. Journal Of Library Administration, 50(5/6), 443-457.

Bowler, M. \& Street, K. (2008). Investigating the efficacy of embedment: Experiments in information literacy integration. Reference Services Review, 36(4), 438-449.

Brown, R., \& Albright, K. (2013). The Google online marketing challenge and distributed learning. Journal Of Education For Library \& Information Science, 54(1), 22-36.

Connaway, L.S. \& Dickey, T.J. (2010). Digital information seeker report of the findings from selected OCLC, RIN and JISC user behaviour projects. Retrieved from http://www.jisc.ac.uk/publications/reports/2010/digitalinformationseekers.aspx

Duke, L., MacDonald, J. \& Trimble, C. (2009). Collaboration between marketing students and the library: An experiential learning project to promote reference services. College \& Libraries, March, 109-121.

Fister, B. \& Eland, T. (2008). Curriculum issues in information literacy instruction. In ACRL (Eds.), Information Literacy Instruction Handbook (pp. 94-103). Chicago, IL: ACRL.

Forbes, C. (2007). Integrating discipline-based library instruction into the curriculum. In Research within the disciplines (pp. 223-240). Lanham, MD: Scarecrow Press.

Gandhi, S. (2003). Academic librarians and distance education. Reference \& User Services Quarterly, 43(2), 138-154.

Higher Learning Commission (2012). Criteria for accreditation. Retrieved from http://www.ncahlc.org/Information-for-Institutions/criteria-for-accreditation.html

Instructor-librarian collaboration can improve course, make librarian more effective. (2005). Distance Education Report, 9(21), 8.

Lih-Juan, C., \& Chwen-Chwen Chang, B. (2003). Web-based library instruction for promoting information skills. Journal of Instructional Psychology, 30(4), 265-275.

Markgraf, J. S. (2004). Librarian participation in the online classroom. Internet Reference Services Quarterly, 9(1/2), 5-19. doi:10.1300/J136v09n01_02

Matthew, V., \& Schroeder, A. (2006). The embedded librarian program. EDUCAUSE Quarterly, 29(4), 61-65.

Middle States Higher Commission, (2006). Characteristics of excellence in higher education requirements for affiliation and standards for accreditation. Retrieved from: http://www.msche.org/publications/CHX-2011WEB.pdf

Owusu-Ansah, E. (2004). Information literacy and higher education : Placing the academic library in the center of a comprehensive solution. Journal of Academic Librarianship 30(1), 3-16.

Riedel, T. (2002). Added value, multiple choices: Librarian/faculty collaboration in online course development. Journal of Library Administration, 37(3/4), 477.

Saunders, L. (2008). Perspectives on accreditation and information literacy as reflected in the literature of library and information science. The Journal of Academic Librarianship, 34(4), 305-313. 
Shank, J. D., \& Dewald, N. H. (2003). Establishing our presence in courseware: Adding library services to the virtual classroom. Information Technology \& Libraries, 22(1), 38.

Standards for distance learning library services. (2008). College \& Research Libraries News, 69(9), 558-569.

Tumbleson, B. E., \& Burke, J. J. (2010). When life hands you lemons: Overcoming obstacles to expand services in an embedded librarian program. Journal of Library Administration, 50(7/8), 972-988. doi:10.1080/01930826.2010.489002

Tyler, K., \& Hastings, N. (2011). Factors Influencing Virtual Patron Satisfaction with Online Library Resources and Services. Journal Of Educators Online, 8(2), 1-34.

West-Pawl, V. (2012). The embedded librarian: Is it enough? Colorado Libraries, 36(3). Retrieved from http://www.coloradolibrariesjournal.org

York, A. C., \& Vance, J. M. (2009). Taking Library Instruction into the Online Classroom: Best Practices for Embedded Librarians. Journal of Library Administration, 49(1/2), 197-209. doi:10.1080/01930820802312995

Jennifer Murphy

Jones International University

Denver, CO

Jlmurph928@gmail.com 


\section{Appendix A}

[University] Information Literacy Standards

It is the objective of [the University] that all students graduate having achieved Information Literacy in which students are taught to "leverage information and technology to amplify personal and organizational achievement and promote information literacy" and to "think analytically, critically and systemically to prepare for a life of learning and accomplishment" ([University] Institutional Learning Outcomes. Students, instructors, librarians, course designers and academic affairs are all partners in achieving Information Literacy for [University] graduates. To this end students are not only instructed on how to use research tools, but taught Information Literacy concepts and skills that transfer across life's challenges and enable life-long learning. Courses are developed, weaving Information Literacy standards throughout, and integrate these concepts in order to help students "construct a framework for learning how to learn" (ALA:

http://www.ala.org/acrl/standards/informationliteracycompetency\#ilhed).

"Every degree program offered by the institution engages students in collecting, analyzing, and communicating information; in mastering modes of inquiry or creative work; and in developing skills adaptable to changing environments." ([University] Academic Master Plan 3B3) These skills are acquired and transferred from course to course and upon graduating the student has amassed lifelong learning skills.

\section{[University] Definition of Information literacy}

The ability to:

- Recognize when information is needed

- Define the problem

- Evaluate and select appropriate resources

- Access and acquire information

- understand how to adapt and/or apply that knowledge

- Understand the legal and ethical obligations related to the access and use of information, including avoiding plagiarism and using correct citation.

\section{Appendix B}

In this assignment, you will use the readings and themes in this module to find three solid resources for your course project. Two sources will come from the [University] Library, and one source will come from the Internet. Your course project requires at least three sources; however, students who want to excel in their studies will often go above the minimum requirements.

1. Using three of the five framing questions and the research proposal that you developed in Assignment 3.2 along with your Forum discussion from this module, identify three strong sources that can help you answer your framing questions. You must use the universal framing question asking about the qualifications you will need to acquire as one of the three framing questions for this assignment. For this assignment, locate:

- Two sources from the [University] Library. Use the Everything tab in the [University] Library to search for sources. You should consider contacting a [University] librarian for help as you complete this step. The library might be a good area for discovering articles covering $21^{\text {st }}$ century job skills, workplace competencies that employers value, changing skill sets in particular careers, job qualifications, etc. 